\title{
A Review of the Metalliferous Mineralization of the Lower Paleozoic Fiambalá Mafic-Ultramafic Complex, Argentina
}

\author{
Luisa M. Villar ${ }^{1}$, Carlos J. Chernicoff ${ }^{2 *}$ \\ ${ }^{I}$ Freelance Geologist, Echeverría 912, Buenos Aires, Argentina. \\ ${ }^{2}$ Consejo Nacional de Investigaciones Científicas y Técnicas, clo Servicio Geológico-Minero Argentino, Predio \\ INTI - Edificio 25, San Martín, Buenos Aires province, Argentina.
}

\begin{abstract}
*Corresponding Author: Carlos J. Chernicoff, Consejo Nacional de Investigaciones Científicas y Técnicas, clo Servicio Geológico-Minero Argentino, Predio INTI - Edificio 25, San Martín, Buenos Aires province, Argentina.
\end{abstract}

\begin{abstract}
The $\mathrm{Cr}+\mathrm{Ni}+\mathrm{Co}+\mathrm{PGE}$ elements occurring at the Sierra de Fiambalá, Argentina (ca. $27^{\circ} 49^{\prime} \mathrm{S}$ $67^{\circ} 30^{\prime} \mathrm{W}$ ) are known to be genetically related to a Lower Paleozoic layered Mafic-Ultramafic (Fiambalá) Complex, where the mineralization is concentrated in the basal ultramafic layer formed by spinel dunites overlain by lherzolites, websterites and gabbronorites. The profiles of PGE fractionation of the Fiambala lherzolites have the same characteristic signature -PGE concentrated in the sulfurized phase, with enrichment in Pt and Pd-of other layered mafic-ultramafic complexes such us the Bushveld and Stillwater complexes, developed in extensional contexts. The latter context may seem to be inconsistent with the Fiambala Complex representing the root of a magmatic arc, but the fact that the locus of this Lower Paleozoic magmatic arc is known to have undergone extensive rifting during the Neoproterozoic (possibly up to Cambrian times) allows the present authors to propose that the Fiambala Mafic-Ultramafic Complex has some geochemical and metalliferous inheritance from the predecessor extensional regime, whereby fragments of pre-existing MORB basement may have been assimilated into the parental magma of the Fiambala Complex, represented by a number of samples collected near the western margin of the Complex, in the vicinity of a postulated feeder dyke.
\end{abstract}

Keywords: Fiambalá Mafic-Ultramafic Complex, layered intrusion, Platinum Group Elements, Lower Paleozoic, Argentina.

\section{INTRODUCTION}

The $\mathrm{Cr}+\mathrm{Ni}+\mathrm{Co}+$ platinum group elements occurring at Fiambalá, Catamarca province, Argentina, are known to be genetically related to a gabbronoritic pluton exposed at this locality. The Fiambalá

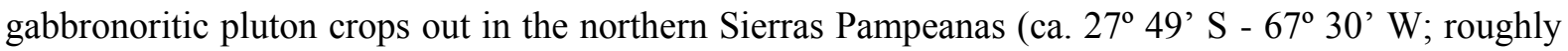
$30 \mathrm{~km}$ northwest of Tinogasta town; Fig. 1), between the Cuestanzune and Salto creeks, within the Agua del Salto mining district (Sierra Fiambalá eastern flank), reaching also the Agua de los Ratones mining district (Sierra Fiambalá western flank).

The protracted history of the discovery of the Fiambalá mineralization starts with the early identification of asbestos at the Salto creek [1], followed by the recognition of the Fiambala Ultramafic Belt [2], and detailed mapping plus studies of the actual metalliferous content of this mineral occurrence [3][4][5][6][7][8][9]. The overall study was completed by a number of exploratory drillings (ca. 120-300 deep) performed by the Mining Secretariat of Argentina (Fig. 1), whose outcome results were firstly discussed by Grissom et al. [10], Page et al. [11] and DeBari[12]. The study specifically focused on the platinum content of the core samples was carried out by Villar et al. [13][14][15], having remained as unpublished reports for the last twenty five years.

Therefore, the main object of the present article is to make the latter study about the platinum content of the Fiambalá core samples known, and to review its geological context. 


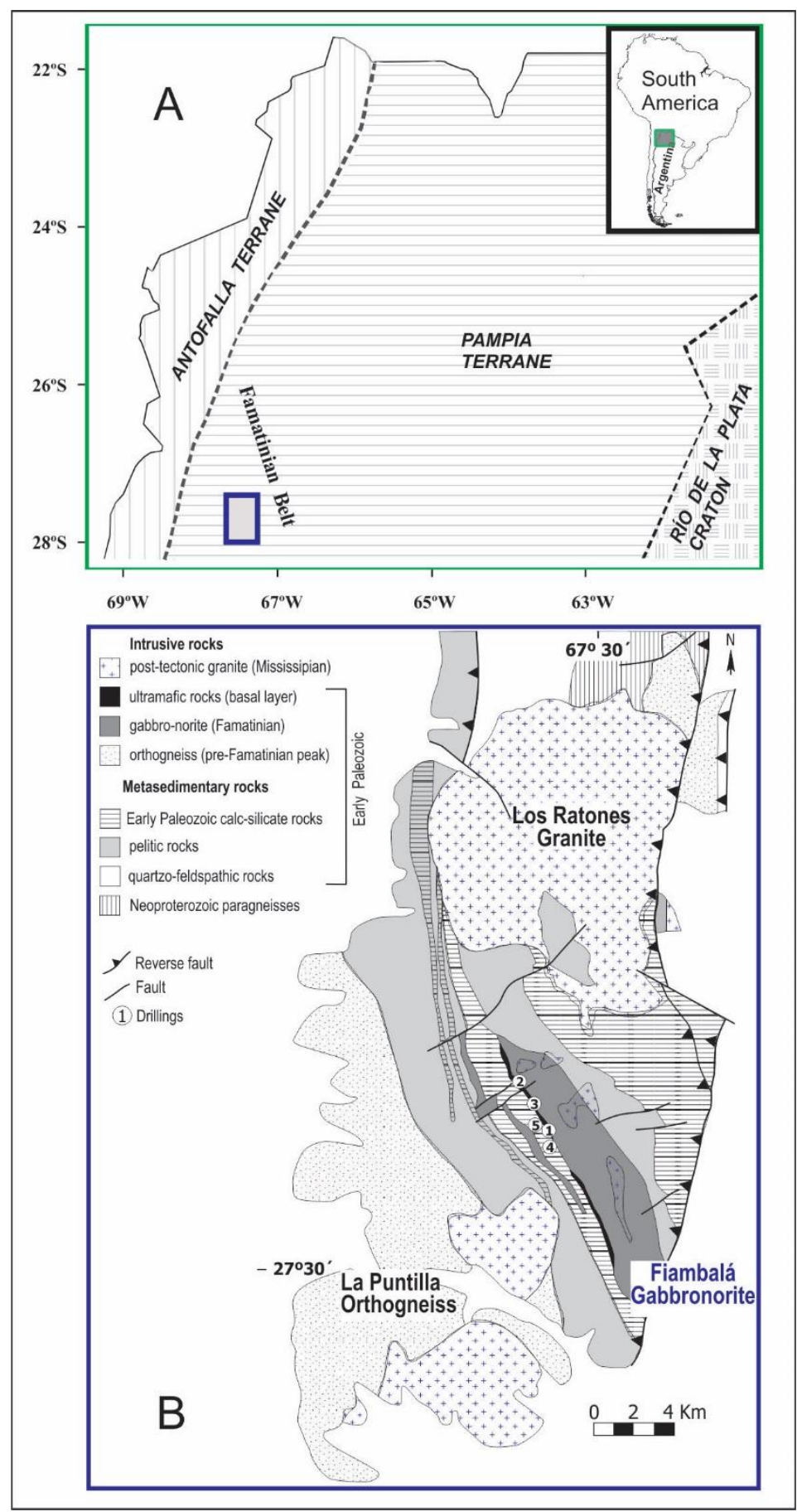

Fig1.A: Geographic and tectonic context of the Fiambala district (blue rectangle) in northwestern Argentina; B: Simplified geological map of the Fiambala Gabbronorite in the broader Fiambala district.

\section{REgional GEOLOGY}

The Sierra de Fiambala is one of the blocks of Late Proterozoic to Early Paleozoic metamorphic basement uplifted during the Andean orogeny to the west of the Río de la Plata craton, forming part of the Sierras Pampeanas [16], and being located at the northwestern edge of the latter range.

In this context, the broader Sierra de Fiambalá block was upthrust towards the east over Tertiaryarkoses and conglomerates; the reverse fault causing this tectonic contact dips roughly $40^{\circ}$ towards the west.

In turn, the Sierra de Fiambalá itself is formed by two smaller -a northern and a southern- blocks thought to be separated by a mylonitic zone largely obscured by the postectonic (Mississipian) Los Ratones Granite. In this article we focus attention on the southern block, which hosts the gabbronoritic unit. 
The southern block is constituted by a partly migmatized metamorphic complex interpreted to be derived from sedimentary protoliths [11] formed by mica schists, gneisses and migmatitic gneisses, as well as by orthogneisses referred to as the La Puntilla orthogneiss. The latter unit stands out in the southwestern portion of the block, whereas the Fiambalá gabbronoritic pluton, as well as basanite dykes and $\mathrm{Sn}-\mathrm{W}-\mathrm{Fe}$ bearing greisens associated to postectonic granites are exposed in the central part of the block (e.g. [17][12]).

The compositional layering of the metamorphic complex is thought to be coeval with the intrusion of the La Puntilla orthogneiss at Early Cambrian times, as suggested e.g. by the growth of lineated sillimanite on the compositional layering planes of the metamorphic complex (e.g. [18]).

Both the sedimentary and igneous protoliths underwent two events of deformation and metamorphism, particularly conspicuous in the metasediments, i.e. Metagrawacke Unit (quartzfeldspar metapelites) and Metacalc-silicatic Unit (calc-silicatic metasediments).

The first deformational event $S_{1}$ is associated with the pervasive crystallization of biotite cutting the $\mathrm{S}_{0}$ bedding surfaces.

The second event is coeval with the roughly conformable intrusion of the Fiambala gabbronorite hence regarded as a syntectonic body; a WNW-trending $\mathrm{S}_{2}$ foliation was superimposed during this event, representing the axial plane of isoclinal folds that also affect the gabbronorite.

The two events of deformation are associated with peaks of metamorphism, i.e. greenschist facies and amphibolite togranulite facies. The amphibolite facies is most spread and conspicuous in the study area, with evidence of later retrogression (e.g. [11]).

The gabbronoritic pluton is hosted both by the Metacalc-silicate Unit (southwestern contact) and the Metagrawacke Unit (northeastern contact), both being partly migmatized.

The intrusion of the gabbronoritic pluton occurred during the peak of the second event of deformation, causing an aureole of thermal metamorphism that grades in intensity in terms of its distance from the plutonic body reaching granulite amphibolite facies.

The latter effect on the calc-silicatic sedimentary host rocks is evidenced by the formation of the association diopside+garnet+quartz, its isogrades being defined by the occurrence (or consumption) of e.g. diopside, tremolite, escapolite and wollastonite and, in the metagrawackes, by the occurrence of hyperstene, microcline, muscovite and sillimanite (e.g. [6], [10]).

The thermal peak is coeval with the intrusion of the gabbronoritic body. The thermal and barometric studies of the aureole of thermal metamorphism caused by the latter intrusion on its host rocks indicate that this event occurred at a pressure of $7.4+-0.9 \mathrm{~kb}$ and a temperature of $800^{\mathrm{a}} \mathrm{C}$, pointing to a depth of $25 \mathrm{~km}$ for the whole Sierra de Fiambalá association, hence regarded as originated in the lower crust [10].

The intrusive body is narrow -maximum width $3 \mathrm{~km}$ wide- and extends for about $12 \mathrm{~km}$ in a NNWSSE orientation, its exposed surface reaching ca. 30 square kilometers. The NNW-SSE orientation is regarded to be parallel to the $S_{2}$ surface [7][10][12].

It is considered that the outcrop of the gabbronoritic body exposes a vertical section, the southwestern abrupt contact representing the bottom, and the northeastern gradual contact representing the top (Figure 1). Notably, the faults bounding the Sierra de Fiambalá association are Paleozoic -not Cenozoic- like the overall deformational event associated with this mountain range (e.g. [19]).

The layered nature of the intrusive Fiambala Complex is evidenced e.g. by the occurrence of two ultramafic sections : 1) one at the basal part of the complex coinciding with its southwestern contact and 2) one in the middle section of the complex (not drilled), in addition to the overall mineralogical variation. However, in the context of the Famatinian (Lower Paleozoic) compressional regime occurred in the Sierra de Fiambalá, the existence of a tectonic repetition of these ultramafic layers cannot be precluded.

The basal ultramafic layer has a maximum (drilled) thickness of $300 \mathrm{~m}$. The ultramafic rocks are dunites overlain by lherzolites and websterites, in turn overlain by gabbro and gabbronorites [6][11]. In accordance to DeBari [12] the sequence is dunite to lherzolite, and wherlite to websterite.

The pyroxenites (websterites) often have mesocumular textures, there being thin layers of anorthosite [11]. Along the southwestern contact and far from the northeastern contact there are gabbro sills intruded. 
The Fiambala Complex presents serpentinization of the basal cumulates and scarce uralitization of the pyroxenes in the gabbros.

In accordance to DeBari [20], both the profiles of the REE and that of the incompatible elements of the gabbros and gabbronorites are indicative of subduction zone.

The tectonic setting of the Fiambala mafic-ultramafic complex corresponds to the lower part of a continental magmatic arc, namely the Cambro-Ordovician Famatinian magmatic arc, that gave rise to the mafic-ultramafic plutonism of the Western Sierras Pampeanas and the Puna region (e.g. [10][11]), and would form the western part of the Sierras Pampeanas at the latitude of the Fiambala gabbronorite (e.g. Ramos [21] amongst others).

As regards geochonological studies, the U-Pb zircon crystallization age of the Fiambalá gabbronorite is constrained to $510-515 \mathrm{Ma}$ [18], which is within the uncertainty of a Sm-Nd mineral isochron (clinopyroxene, plagioclase, whole-rock) age of 501+21Ma for a two-pyroxene gabbro [12].

In addition, a K/Ar dating on flogopite from the ultramafic body yielded $415 \pm 20 \mathrm{Ma}$ (unpublished laboratory data), and is interpreted to have formed during metamorphic differentiation, a process typical in ultramafic bodies, corresponding to the late stage of the magmatic activity.

\section{Key Petrography}

The ultramafic unit is formed by a) dunites, which are adcumulates of olivine+chromite (olivine $95 \%$, orthopyroxene+ clinopyroxene 0 a $4 \%$, chromite $0.9 \%$; the pure dunites are extreme adcumulates of olivine with chromite, b) lherzolites, which are adcumulates of olivine $(80 \%)$, orthopyroxene (5 to $10 \%$ ), clinopyroxene (5 to10\%) and spinel (1 to 2\%), c) wherlites, formed by olivine (70 to 80\%), clinopyroxene (20 a 30\%), chromiferous spinel (2\%), d) websterites, formed by orthopyroxene (5 to $10 \%)+$ clinopyroxene $(60$ to $95 \%)$ and $<1 \%$ spinel; when there also occurs interstitial plagioclase these rocks turn into mesocumulates, e) norites, formed by orthopyroxene (15 to 35\%) + plagioclase (45 to 60\%), f) gabbronorites, formed by orthopyroxene (15-35\%), clinopyroxene (5-30\%), plagioclase (45-60\%), amphibolite (0-30\%) and ilmenite (0-5\%), and g) gabbros, formed by plagioclase+clinopyroxene+amphibole. The igneous textures of these rocks vary up to metamorphic textures characterized by banding and triple point angles [6][12].

\section{Key Mineralization}

The mineralizations associated with the gabbroid pluton of Fiambalá are of magmatic type, characterizing the different lithologies related with the layering of the intrusive body. The mineralization found in the basal dunite consists of chromite, magnetite, ilmenite, awaruite, heazlewoodite and native gold sparks, that in the lherzolites and websterites consists of chromite, magnetite, ilmenite, pyrrhotine, pentlandite and native gold sparks, and that found in the gabbros, gabbronorites and norites consists of pyrrhotine, pentlandite, chalcopyrite, zinc blende, ilmenite, magnetite, mackinawite, native gold sparks, violarite, covellite and digenite. The PGE are in some cases beared by the chromites and the sulphides.

In addition to the above mentioned mineralizations, there also exists a hydrothermal mineralization in the host calc-silicatic metasediments formed mainly by graphite, pyrite, chalcopyrite, pyrrotite, pentlandite and mackinawite, related the remobilization of the ore minerals contained in the gabbroid pluton. The basalts interleaved in the ultramafic rocks bear scares pyrite and chalcopyrite.

The primary minerals are: chromite, magnetite, awaruite, heazlewoodite, pentlandite, pyrrotite, mackinawite, ilmenite, chalk opyrite, zinc blende, native gold and pyrite [4][22][23][6].

The secondary minerals are: magnetite, hematite, martite, marcasite, leucoxene, pyrite, violarite, covellite, digenite and y limonites. The hematite as an alteration of primary magnetite is found in veins and veinlets, and forms patinas. The marcasite derives from the alteration of pyrite and pyrrotite. The violarite is scarce, and it is associated with pyrite and relics of pentlandite with typical orthorrombic cleavage. The covellite is found as scattered flakes, either as aggregates or associated with pyrrotite, pyrite and diagenite, forming part of veins and veinlets. The diagenite is found either as isolated flakes, or associated with pyrrotite, pyrite and supergenic covellite [4][22][23][6].

\section{Metalliferous Content}

Table 1 shows the metalliferous content of the Fiambalá complex. The maximum values of the metals of economic interest are between 1800 and $2600 \mathrm{ppm} \mathrm{Ni}$ in the basal dunite (there also exists a 
A Review of the Metalliferous Mineralization of the Lower Paleozoic Fiambalá Mafic-Ultramafic Complex, Argentina

maximum value of $4000 \mathrm{ppm}$ at surface level, enriched by weathering), 810 to $2300 \mathrm{ppm} \mathrm{Ni}$ in the lherzolites, and 20 to $240 \mathrm{ppm} \mathrm{Ni}$ in the gabbronorites (the latter relatively lower $\mathrm{Ni}$ values in the gabbronorites are consistent with their position away from the basal part of the intrusive body). The maximum $\mathrm{Cr}$ content is 860 to $1300 \mathrm{ppm}$ in the dunites, 1200 to $2500 \mathrm{ppm}$ in the lherzolites, and 52 to $990 \mathrm{ppm}$ in the gabbronorites (gabbros and metagabbros). The maximum Co content is 79 to 100 $\mathrm{ppm}$ in the dunites, 59 to $130 \mathrm{ppm}$ in the lherzolites, and 46 to $59 \mathrm{ppm}$ in the gabbronorites, the values again lowering topward the unit. The maximum $\mathrm{Cu}$ content is $<2$ to $32 \mathrm{ppm}$ in the basal dunite, 180 to $490 \mathrm{ppm}$ in the lherzolites, and 28 to $180 \mathrm{ppm}$ in the gabbronorites. Zinc content ranges 20 to $140 \mathrm{ppm}$ in the basal dunite, 53 to $79 \mathrm{ppm}$ in the lherzolites, and 73 to $120 \mathrm{ppm}$ in the gabbronorites, gabbros and metagabbros. The latter values coincide with the occurrence of zinc blende related to hydrothermal activity, also associated with zeolitization.

Table1. Metalliferous content of the Fiambala Mafic-Ultramafic Complex. Methods: Atomic absorption spectrometry (NOA I Plan, Argentine Mining Secretariat) and optic spectroscopy (Geochemistry Lab, U.S.G.S.).

\begin{tabular}{|c|c|c|c|c|c|}
\hline & \multicolumn{5}{|c|}{ ELEMENTS } \\
\hline IGNEOUS FACIES & $\mathrm{Cr}(\mathrm{ppm})$ & $\mathrm{Ni}(\mathrm{ppm})$ & $\mathrm{Co}(\mathrm{ppm})$ & $\mathrm{Cu}(\mathrm{ppm})$ & $\mathrm{Zn}(\mathrm{ppm})$ \\
\hline BASAL DUNITE & $860-1300$ & $1800-2600$ & $79-100$ & $<2-32$ & $20-140$ \\
\hline LHERZOLITE & $1200-2500$ & $810-2300$ & $59-130$ & $180-490$ & $53-79$ \\
\hline GABBRONORITE & $52-990$ & $20-240$ & $46-59$ & $28-180$ & $73-120$ \\
\hline
\end{tabular}

The PGE analyzed both from drill cores and outcrops reach 93 samples. The results from the 38 PGE -bearing samples are shown in Table 2. The PGE are mainly found in the lherzolites and, exceptionally, in the gabbronorites, gabbros and norites, their contents reaching economic interest [24]. This distribution of values can also be seen in the original core logs of the Fiambalá drillings \#1 and \#3 [6] that traversed solely the intrusive body, firstly detecting its lithologic zoning at depth.

Table2. PGE contents of the Fiambalá Mafic-Ultramafic Complex. Methods: Fire Assay and Neutronic Activation (U.S.G.S.).

\begin{tabular}{|c|c|c|c|c|}
\hline FACIES TYPE & DUNITES & LHERZOLITES & WEBSTERITES & GABBROS/GABBRONORITES \\
\hline Platinoids & $\mathrm{ppb}$ & $\mathrm{ppb}$ & $\mathrm{ppb}$ & $\mathrm{ppb}$ \\
\hline $\mathrm{Pt}$ & $1-9.7$ & $4.2-21$ & 17 & $0.9-150$ \\
\hline $\mathrm{Pd}$ & $1-6.3$ & $4.5-32$ & 20 & $<0.8-3.4$ \\
\hline $\mathrm{Rh}$ & $<0.5-1.8$ & $<0.5-1.4$ & 1 & $<0.4-1.0$ \\
\hline $\mathrm{Ru}$ & $1.2-8.3$ & $<0.5-3.2$ & 2.6 & $<0.5-5.5$ \\
\hline $\mathrm{Ir}$ & $0.6-5.5$ & $<0.5-1.4$ & 0.9 & $<0.5-8.0$ \\
\hline
\end{tabular}

\section{DRILLINGS}

Figure 2 shows unpublished core $\operatorname{logs}$ of the Fiambalá Complex, figure $2 \mathrm{~A}$ corresponding to platinoids from drillings \#1 and \#3, and figure $2 \mathrm{~B}$ corresponding to $\mathrm{Ni}, \mathrm{Co}, \mathrm{Cr}$ and $\mathrm{Cu}$ from drilling \#1.

Drilling \#1 traverses the basal ultramafic unit formed by dunites, lherzolites and websterites, and the gabbronoritic unit constituted by gabbros and norites; the depth of this drilling reached $300 \mathrm{~m}$, core samples having been intermittently analyzed for platinoid elements (figure $2 \mathrm{~A}$ ) from $14 \mathrm{~m}$ to $281 \mathrm{~m}$.

The first layer traversed was spinel dunite or cumulate of olivine-chromite, referred to as the basal dunite. The mineralization found in the basal dunite consists of chromite, magnetite, ilmenite, awaruite, heazlewoodite and native gold sparks. The mineralization found in the lherzolites and websterites consists of chromite, magnetite, ilmenite, pyrrhotine, pentlandite and native gold sparks.

The mineralization found in the gabbros and gabbronorites consists of pyrrhotine, pentlandite, chalcopyrite, zinc blende and native gold.

In the drilling \#1 the Pt values within the spinel dunites of the basal ultramafic unit range between 3.1 and $5.2 \mathrm{ppb}$, the Pd ranges between 1 and $2.0 \mathrm{ppb}$, the Rh ranges between 0.8 and $1.3 \mathrm{ppb}$, the $\mathrm{Ru}$ ranges between 4.3 and $8.3 \mathrm{ppb}$, and the Ir ranges between 2.3 and $3.4 \mathrm{ppb}$. In the lherzolite zone of the basal ultramafic unit, the Pt ranges between 4.2 and $21 \mathrm{ppb}$, the Pd ranges between 4.6 and 15 $\mathrm{ppb}$, the $\mathrm{Rh}$, slightly depleted with respect to that of the dunite zone, ranges between $<0.5$ and 0.9 $\mathrm{ppb}$; the Ru ranges between $<0.5$ and $2 \mathrm{ppb}$, and the Ir ranges between $<0.5$ and $0.8 \mathrm{ppb}$. In the websterites that are intercalated within the lherzolite zone, Pt reaches $17 \mathrm{ppb}$, Pd reaches $20 \mathrm{ppb}, \mathrm{Rh}$ reaches $1 \mathrm{ppb}$, Ru reaches $2.6 \mathrm{ppb}$ and Ir reaches $0.9 \mathrm{ppb}$.

All in all, in the drilling \#1, the Pt and Pd are concentrated in the lherzolite-websterite, whereas the $\mathrm{Rh}, \mathrm{Ru}$ and $\mathrm{Ir}$ have higher values in the zone of the spinel dunites of the basal ultramafic unit. The 
gabbros and norites of the gabbronoritic unit (that in some cases can be referred to as metagabbros and metagabbronorites when slight metamorphism is detected) are depleted in platinoid elements.

The drilling \#2 (Fig. 3) traversed the dunite lens, the calc-silicatic metasediments and, again the basal dunite of the basal ultramafic unit. The depth of this drilling reached $226 \mathrm{~m}$, from which $165 \mathrm{~m}$ were core sampled intermittently for analyzing the content of platinoid elements. The basal dunite contains the same mineralization detected in drilling \#1 (see above). The mineralization identified in the calcsilicate metasediments consists of graphite, pyrite, chalcopyrite, pyrrhotite, pentlandite and mackinawite.

The Pt values found in the dunite upper zone (dunite lens) range between 1.0 and $9.7 \mathrm{ppb}$, those of $\mathrm{Pd}$ range between $<1$ and $6.3 \mathrm{ppb}$; Rh values range between $<0.5$ and $1.8 \mathrm{ppb}$, Ru values range between 1.2 and $7.2 \mathrm{ppb}$, and Ir values range between 0.6 and $5.5 \mathrm{ppb}$. In the second (lower) dunite lens, at a depth of $182 \mathrm{~m}$, the Pt content is $5.6 \mathrm{ppb}$, the Pd content is $1.0 \mathrm{ppb}$, the Rh content is $1.2 \mathrm{ppb}$, the Ru content is $7.7 \mathrm{ppb}$ and the Ir content is $8.8 \mathrm{ppb}$ (see Table 2). In the calc-silicatic metasediments traversed by this drilling \#2 there is a complete absence of platinoid elements. At the depth of $155 \mathrm{~m}$ this drilling traversed what is interpreted as boudins of metagabbros whose PGE content reaches maximum values of $5.6 \mathrm{ppb} \mathrm{Pt}, 3.2 \mathrm{ppb} \mathrm{Pd}, 1.0 \mathrm{ppb} \mathrm{Rh}, 5.5 \mathrm{ppb} \mathrm{Ru}$ and $0.9 \mathrm{ppb}$ Ir.
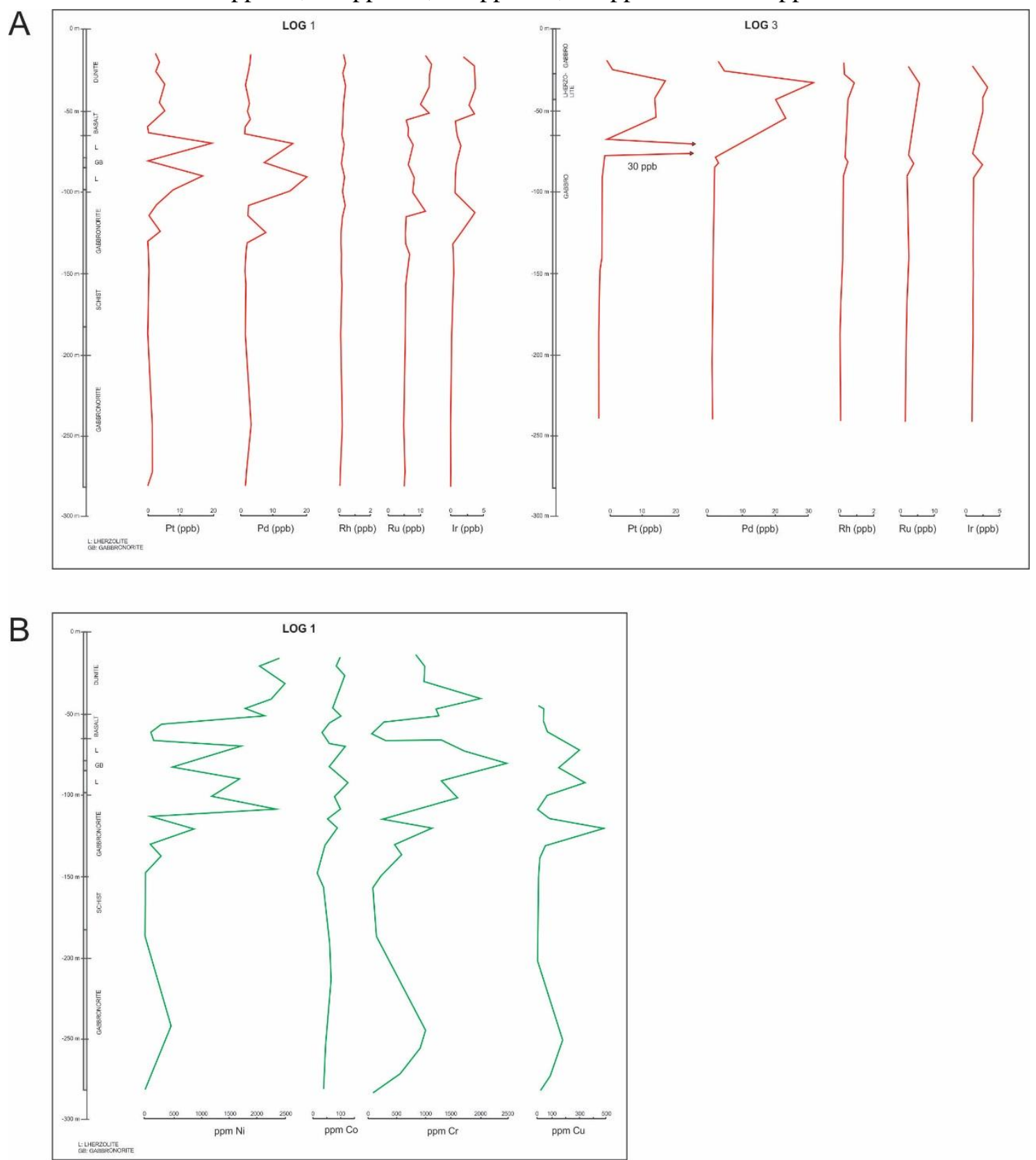

Fig2. Core logs of the Fiambalá Mafic-Ultramafic Complex corresponding to: A) platinoids-drillings \#1 and \#3- and B) $\mathrm{Ni}, \mathrm{Co}$, $\mathrm{Cr}$ and $\mathrm{Cu}$-drilling \#1-. 


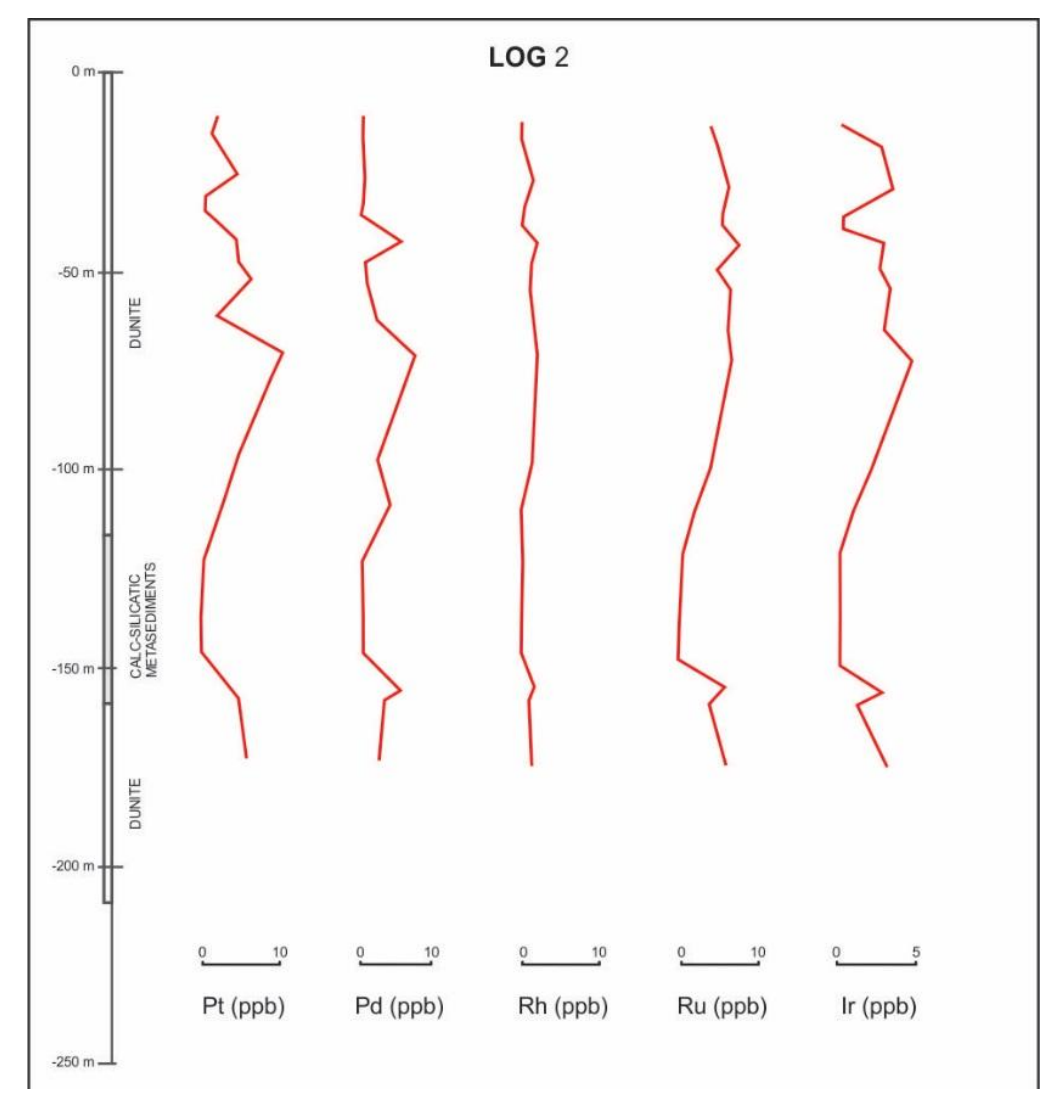

Fig3. Core log of the Fiambala Mafic-Ultramafic Complex corresponding to platinoids -drilling \#2.

Both the drillings \#1 and \#3 traversed -angularly- the lower basal section of the stratified intrusive body -plus part of the overlying gabbronorites-, showing that the $\mathrm{Ni}, \mathrm{Cr}$, Co and PGE content is higher in the basal ultramafic section; these elements reach their maximum particularly in the lherzolite zone, where the sulfurized facies of the basal part of the intrusive is concentrated (see Table 1), [6]. The stratigraphy and maximum depth reached by these drillings \#1 and \#3 are almost identical, this being the reason why in this review we have grouped the core logs of both drillings in a single figure (Fig. 2)

The PGE, especially Pt and Pd, reach their maximum in the lherzolite and websterite zones, with the occurrence of the sulfurized facies of pentlandite, pyrrhotine and chalcopyrite; pentlandite, in particular, is a great capturer of palladium (see Tables 1 and 2, and figure 2A showing the core logs of drillings \#1 and \#3). Both the Ru and Ir reach their maximum in the basal dunite.

The drilling \#3 (Fig. 2) was analyzed intermittently down to $250 \mathrm{~m}$, traversing gabbros and lherzolites, penetrating at depth a zone (possibly boudins) of metagabbros and metagabbronorites (amphibolite facies metamorphism). The mineralization associated with the lherzolites consists of chromite, magnetite, ilmenite, pyrite, chalcopyriye and native gold. The mineralization associated with the (meta)gabbros and (meta)gabbronorites consists of chalcopyrite, pyrrhotite, pentlandite, cubanite, mackiwanite, pyrite, marcasite, native gold and remnants of magnetite and ilmenite.

In the lherzolites, the Pt values range between 12 and $19 \mathrm{ppb}, \mathrm{Pd}$ values range between 13 and $32 \mathrm{ppb}$, $\mathrm{Rh}$ values range between 0.7 and $1.4 \mathrm{ppb}, \mathrm{Ru}$ values range between 1.7 and 3.2, and $\mathrm{Ir}$ values range between 0.7 and $1.1 \mathrm{ppb}$.

In the metagabbros and metagabbronorites of drilling \#3 the Pt values range between 0.9 and $39 \mathrm{ppb}$, $\mathrm{Pd}$ values range between $<0.8$ and $3.4 \mathrm{ppb}$, $\mathrm{Rh}$ values range between $<0.4$ and 0.5 , $\mathrm{Ru}$ values range between $<0.5$ and $0.5 \mathrm{ppb}$ and Ir values range between $<0.5$ and $1.4 \mathrm{ppb}$.

At $70.77 \mathrm{~m}$ depth, the metagabbronorites traversed by the drilling \#3 is notably enriched in Pt that reaches $39 \mathrm{ppb}$ (see Table 2). In this case, this Pt enrichment is accompanied by a decrease in Pd, contrary to what occurs in the lherzolites.

In the drilling \#4 (not shown) only three samples pertaining to the basal dunite were analyzed for platinoids. The content of platinoids is similar to that found in drilling \#1, i.e. Pt ranges between <1 and $3 \mathrm{ppb}$, Rh ranges between 0.5 and $0.9 \mathrm{ppb}$, Ru ranges between 206 and 5.1 and Ir ranges between 1.2 and $3 \mathrm{ppb}$. 
In the drilling \#5 (also not shown) a core sample was analyzed from a highly mineralized metagabbros where Pt content reached $150 \mathrm{ppb}$, whereas Pd reaches $2 \mathrm{ppb}$, Rh reaches $1 \mathrm{ppb}, \mathrm{Ru}$ reaches $1 \mathrm{ppb}$ and Ir reaches $8 \mathrm{ppb}$. Notably, this rock contains the highest Pt content found in the Fiambalá district up to now.

\section{Key PGe Geochemistry And TeCtomagmatic EnVironment}

The chondrite normalized PGE diagrams from samples taken throughout the mafic-ultramafic complex were first shown by Villar [24], as yielding basically two types of profiles, i.e. horizontal for the dunites, and positive slope profiles for the lherzolites, websterites and gabbronorites, hence pointing to two magma types. These two types of magmas also indicate an extreme differentiation of the basal layer of adcumular dunite, whose transition towards the rest of the layers is abrupt -even of tectonic nature, as inferred from the drilled cores.

The PGE elements of the lower layer are concentrated in the chromites, whereas in the upper layers, topward from the lherzolites, the PGE elements are concentrated in the sulphides. Otherwise, Villar [24] have proposed that the erratic enrichment in platinum evidenced by some gabbros (diagram not shown) was caused by hydrothermal activity.

The profiles of PGE fractionation of the Fiambalá spinel dunites are roughly horizontal (Fig. 4A), resembling those of the ophiolites and komatiites; the spinel dunites concentrate the PGE in the spinels, with the concomitant enrichment in Os, Ir and Ru.

The profiles of PGE fractionation of the Fiambalá lherzolites (Fig. 4B) have positive slopes, the PGE being concentrated in the sulfurized phase, with enrichment in Pt and Pd.

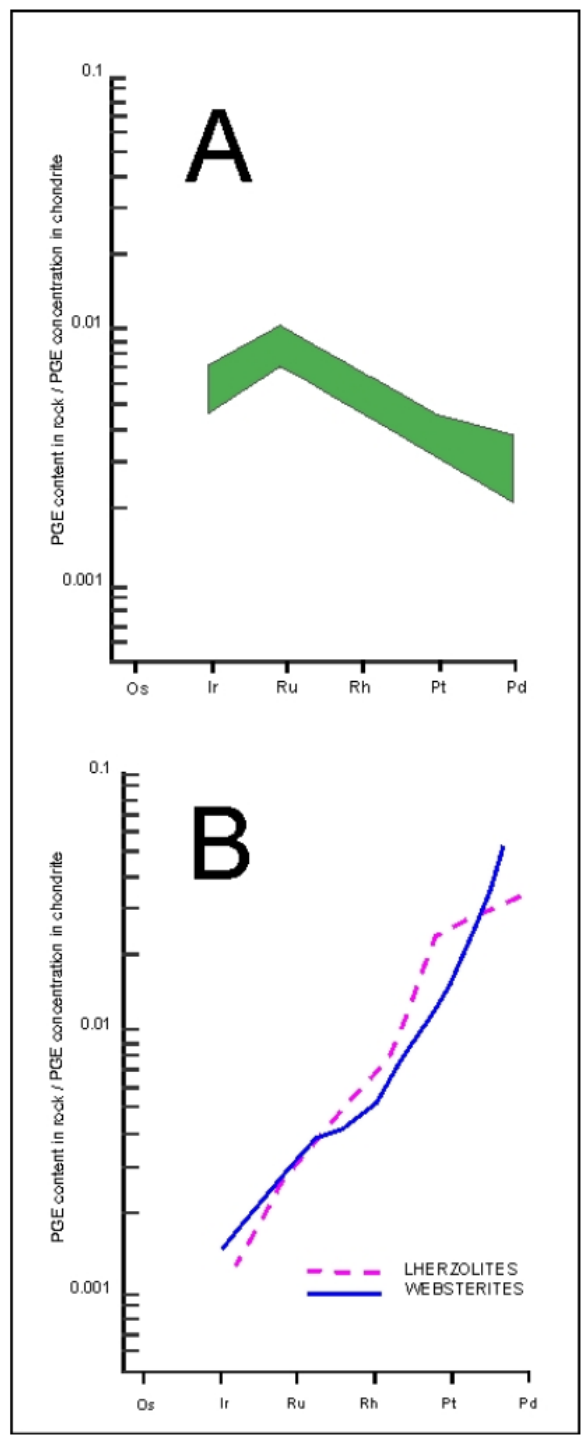

Fig4. A: Area that contains the chondrite normalized PGE profiles corresponding to the spinel dunites of drilling \#1. B: Distribution of chondrite normalized PGE average content of four lherzolites of drilling \#1 (at $70 \mathrm{~m}$ ) and drilling \#3 (at 24, 32 and $45 \mathrm{~m}$ ), plus chondrite normalized PGE content corresponding to the websterite of drilling \# (at $90 \mathrm{~m}$ ). 
In the diagram of figure 5, the $\mathrm{Pd} / \mathrm{Ir}$ versus $\mathrm{Ni} / \mathrm{Cu}$ relationship establishes the tectomagmatic fields for the different groups of mafic and ultramafic rocks, where the field of the ophiolites and that of the layered intrusions overlap. The lherzolites with higher Pt and Pd fall in the field of the layered intrusions within the platiniferous horizons, whereas the spinel dunites fall in the field of the mantle due to the composition and origin of this cumulate.

Similarly, in the Ni/Pd versus $\mathrm{Cu} / \mathrm{Ir}$ diagram (not shown), the lherzolites and websterites fall in the field of the layered intrusions, whereas the basal cumulates of spinel dunites fall in mantle field exclusively due to their composition and/or a very primitive initial origin.

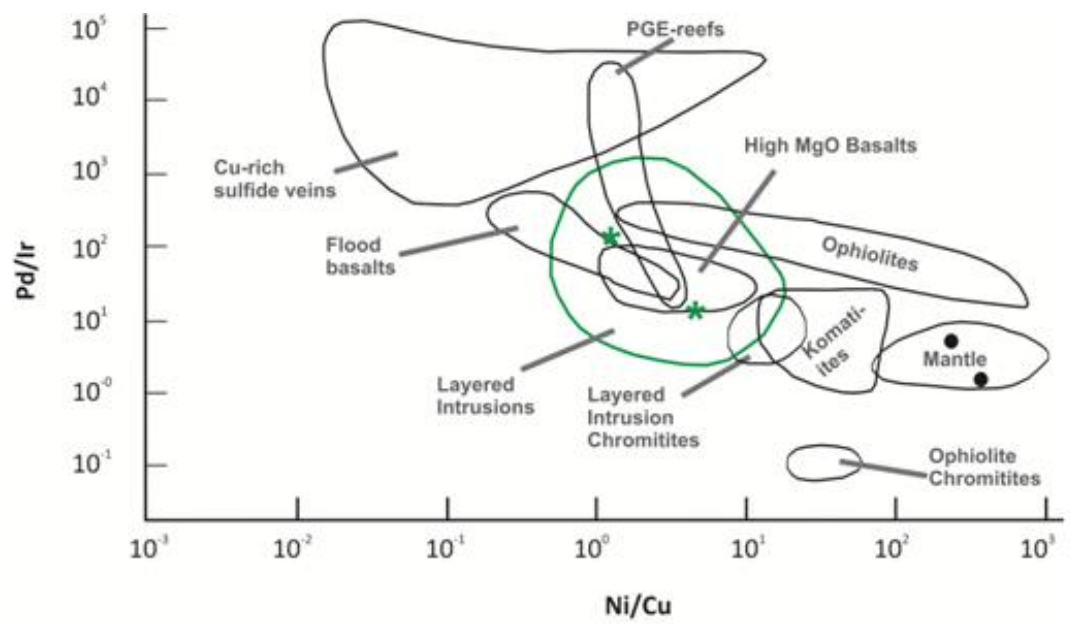

Fig5. Pd/Ir versus Ni/Cu diagram for the PGE-bearing mafic and ultramafic complexes, with fields indicating tectomagmatic origin (simplified after Moggesie and Saini Edukat [25]). Reference: green asterisks: lherzolites; black dots: spinel dunites.

\section{CONCLUSiON}

Concurring arguments allow to classify the Fiambalá mafic-ultramafic body as a layered, where two magma types contributed to its formation, as firstly proposed by DeBari [12] and Villar [24]. Notably, the dunite lens shows thin igneous layering remarked by the isorientation of the chromite grains, this thin layering being unconformable with respect to the strike and dip of the gabbro layers, hence reinforcing the evidence for the dunite lens to have been originated by a magmatic pulse independent from that producing the rest of the cumulates.

The latter evidence is consistent with the differences between two PGE frationation profiles, i.e. roughly horizontal for the dunites, and positive slope profiles for the lherzolites, websterites and gabbronorites. This difference could also explain the lack of sulfurized liquid available to collect Pt in the spinel dunite since, remarkably, chromite tends to concentrate Os, Ir and Ru, whereas Pt and Pd are concentrated in the sulfurized phase predominant in the lherzolites, gabbros and gabbronorites. Otherwise, the Pt enrichment in some gabbros of the Fiambala Complex is bound to be of hydrothermal origin since it is not accompanied by Pd enrichment, as normally occurring in the gabbroid differentiates.

The PGE abundance as a function of the stratigraphy of the Fiambala Complex has been represented in the core $\operatorname{logs}$ corresponding to drillings \#1, \#2 and \#3, indicating that the maximum Pt and Pd values are found in the lherzolites lying immediately on top of the spinel dunites. The latter dunite corresponds to the lowermost part of the basal ultramafic layer, hence representing the floor of the Fiambalá Complex.

The profiles of PGE fractionation of the Fiambalá lherzolites have the same characteristic signature PGE concentrated in the sulfurized phase, with enrichment in Pt and Pd- of other layered maficultramafic complexes such us the Bushveld and Stillwater complexes, developed in extensional contexts. The latter context may seem to be inconsistent with the Fiambalá Complex representing the root of a (Lower Paleozoic) magmatic arc [18], but the fact that the locus of this Lower Paleozoic magmatic arc -i.e. continental margin- is known to have undergone extensive rifting during the Neoproterozoic (possibly up to Cambrian times) -so much so that this segment of the Famatinian arc actually developed on thinned crust [20]) - allows the present authors to propose that the Fiambalá 
Mafic-Ultramafic Complex has some geochemical and metalliferous inheritance from the predecessor extensional regime, whereby fragments of pre-existing MORB basement may have been assimilated into the parental magma of the Fiambalá Complex, represented by a number of samples collected near the western margin of the Complex, in the vicinity of a postulated feeder dyke [12].

This may be consistent with the enriched pattern of the evolved Fiambalá gabbroic rocks relative to MORB, which can be interpreted to be a characteristic of their source, i.e. possibly an enriched sub continental mantle.

The core logs of the Fiambalá Magmatic Complex demonstrate its layered nature and, in the context referred to above, indicate the mining potential of its ultramafic basal layer formed by harzburgites and lherzolites. The lherzolites, in particular, that point to the highest temperature reached by the Complex, constitute the platinoid-bearing marker horizon.

The chromium and most of the $\mathrm{Ni}$ and $\mathrm{Cu}$ sulphides tend to concentrate at the base of the lower ultramafic layer. This lower ultramafic layer underlies the norites and gabbros of the middle and upper sections of the Complex, which are less enriched in metallic elements.

Immediately below the ultramafic basal layer, there is a zone lithologically also of ultramafic character but conspicuously boudinaged at an early stage. Here the boudins are markedly enriched in PGE, reaching as much as $400 \mathrm{ppb}$.

\section{REFERENCES}

[1] Tezón, R.V. and Fernandez Lima J.C.R. 1949. Geología económica de la Hoja 13c . Distrito Los ArbolesLos Ratones, Departamento de Tinogasta, Provincia de Catamarca. Dirección Nacional de Minería. Unpublished Report.

[2] Villar, L.M., 1970. La Faja Ultrabásica de la Sierra de Fiambalá, provincia de Catamarca, República Argentina. Simposio sobre los resultados de Investigaciones del Manto Superior con énfasis en América Latina, 2: 399-409. Buenos Aires.

[3] Villar, L.M., 1972. La faja ultrabásica de la Sierra de Fiambalá y la prospección orientativa de níquel. Servicio Nacional de Minería y Geología, Report 736. Unpublished.

[4] Villar, L.M., Godeas M.C., Segal, S.J. 1978 El basamento facies anfibolita-granulita y la faja ultrabásica de la Sierra de Faimbalá. $7^{\circ}$ Congreso Geológico Argentino. Proceedings II : 521-536.

[5] Villar, L.M.. 1982. Geología de dos sectores de la faja ultrabásica de la Sierra de Fiambalá (Filo del Medio y Agua de los Piques), provincia de Catamarca, Revista de la Asociación Geológica Argentina 37 (2): 287-245.

[6] Villar L.M., Godeas. M.C., Segal, S.J., 1986. Logs de las perforaciones 1, 2, 3 y 4 de la Sierra de Fiambalá. Dirección Nacional de Minería y Geología. Two Volumes, 343 p. Unpublished Report.

[7] Villar, L.M. and Segal S.J., 1988. Correlación geológica y metalogenética de las perforaciones realizadas en la asociación gabrico-sedimentaria de la Sierra de Fiambalá, provincia de Catamarca. $7^{\circ}$ Congreso Latinoamericano de Geología, Belem Pará, Brasil. Anais VI : 39-153.

[8] Roqué C.E., 1976. Area de reserva no 47 Fiambalá -Zapata. Sector Filo del medio y Agua de los Piques Estudios de polarización inducida. Plan NOA Tucumán. Servicio Nacional de Geología y Minería. Unpublished Report.

[9] Roqué C.E., 1978. Area de Reserva na 47 Fiambalá Zapata. Rocas ultrabásicas, Sector Intermedio. Estudio de la geofísica por el método de polarización inducida. Plan NOA. Tucumán. Servicio Nacional de Geología y Minería. Unpublished Report.

[10] Grissom, G, DeBari, S. M., Page, S., Page, R., Villar, L., Coleman, R. G., Ramirez, M., 1992. The deep crust of an early paleozoic arc, the Sierra de Fiambalá, NW Argentina. Andean Magmatism and its Tectonic Setting. Geological Society of America Special Paper 265: 189-200.

[11] Page, S., Page, R.F.N., Viruel de Ramirez, M., 1992. El basamento de la Sierra de Fiambalá, provincia de Catamarca. Revista de la Asociación Geológica Argentina, 47 (4): 373-388.

[12] DeBari, S., 1994. Petrogénesis of the Fiambalá Gabbroic Intrusion, Northwestern Argentina, a Deep Crustal Syntectonic Pluton in a Continental Magmatic Arc. Journal of Petrology, Volume 35. Part 3: 679-713.

[13] Villar, L.M., Donnari, E.I., Segal, S.J., Page, N.J., 1991a. Platinoideos en la faja máfica-ultramáfica de Cordillera Frontal de Mendoza y el gabro de Fiambalá. I Jornadas de Mineralogía, Petrografía y Metalogénesis de rocas ultramáficas: 475-489.

[14] Villar, L.M., Segal, S. J., Page, N.J., 1991b. Presencia de platinoides en el gabro de Fiambalá, provincia de Catamarca, Argentina. $5^{\circ}$ Congreso Geológico Chileno, Proceedings: 588-592. 
[15] Villar, L. M., Segal, S. J., Page, N.J. 1993. Platinum Group elements in the Gabbro of Fiambalá, province of Catamarca, Argentina. I Brazilian PGE Meeting: 60-62.

[16] Gonzalez Bonorino, F., 1950. Algunos problemas geológicos de las Sierras Pampeanas. Revista de la Asociación Geológica Argentina 3: 81-110.

[17] Villar, L.M., Segal, S. J., Godeas, M.C., 1981. Hallazgo de sulfuros de hierro, cobre, niquel, zinc y plomo en relación con la faja ultrabásica y la escama de alto grado de metamorfismo, Sierra de Fiambalá, provincia de Catamarca. Revista de la Asociación Geológica Argentina 36 (2): 143-197.

[18] Grissom, G.C., Debari, S.M., Lawrence, W.S., 1998. Geology of the Sierra de Fiambala, northwestern Argentina: implications for early Palaezoic Andean tectonics. In: Pankhurst, R.J., Rapela, C.W. (Eds.). The Proto-Andean Margin of Gondwana. Geological Society, London, Special Publications 142: 297-323.

[19] Villar, L.M., Coleman, R.G., 1986. Reinterpretación geológica de la faja ultrabásica y el bloque de alto grado de metamorfismo, Provincia de Catamarca. Revista de la Asociación Geológica Argentina 41(3-4): 410-413.

[20] DeBari, S., 1997. Evolution of magmas in continental and oceanic arcs: the role of the lower crust. The Canadian Mineralogist 35: 501-519.

[21] Ramos, V.A., 2017. Las provincias geológicas del noroeste argentino. In: Muruaga, C.M., Grosse, P. (Eds.), Ciencias de la Tierra y Recursos Naturales del NOA. Relatorio del $20^{\circ}$ Congreso Geológico Argentino, Relatorio: 42-56. San Miguel de Tucumán.

[22] Villar, L.M., Godeas, M.C., Segal, S.J., 1979. Geología y petrología de la faja ultramáfica de la Sierra de Fiambalá y su basamento asociado, inferida del estudio en detalle de los subsectores Filo del Medio y Agua de los Piques, del Area de Reserva Fiambalá-Zapata, provincia de Catamarca. Servicio Minero Nacional. Unpublished Report. 42p.

[23] Villar, L.M., Segal S.J., Godeas, M.C., 1983. Mineralización y génesis de la faja ultrabásica y las metamorfitas de alto grado asociadas, Sierra de Fiambalá, provincia de Catamarca, $1^{\circ}$ Congreso Nacional de Geología Económica, Argentina. Proceedings I: 143-159.

[24] Villar, L.M., Segal, S.J., Page, N. J., 1996. Los platinoideos del plutón gabroide de Fiambalá, provincia de Catamarca, Argentina. 13 Congreso geológico Argentino, Proceedings III: 189-200.

[25] Mogessie, E.A. and Saini Edukat, B.., 1992. A review of the ocurrence of platinum group elements in Duluth Complex, Minnesota. Trends in Mineralogy. 1: 65-85.

Citation: Luisa M. Villar, Carlos J. Chernicoff, (2019)" A Review of the Metalliferous Mineralization of the Lower Paleozoic Fiambalá Mafic-Ultramafic Complex, Argentina”, Southeast Cameroon, International Journal of Mining Science (IJMS), 5(3), pp.23-33, DOI: http://dx.doi.org/10.20431/2454-9460.0503004

Copyright: () 2019 Authors. This is an open-access article distributed under the terms of the Creative Commons Attribution License, which permits unrestricted use, distribution, and reproduction in any medium, provided the original author and source are credited 